\title{
From Acute Disease to Red Flags: A Review of the Diverse Spectrum of Red Eye Encountered in the Primary Care Setting \\ Van Charles Lansingh ${ }^{1,2 *}$, Kristen Allison Eckert ${ }^{3}$, Stephanie Voorduin Ramos ${ }^{4}$ and Ellery M López Star ${ }^{1}$
}

${ }^{1}$ Mexican Institute of Ophthalmology (IMO), Queretaro, Mexico

${ }^{2} \mathrm{Help}$ Me See, New York, USA

${ }^{3}$ Independent Consultant, San Antonio Tlayacapan, Jalisco, Mexico

${ }^{4}$ Hospital Nuestra Señora de la Luz Foundation, Mexico City, Mexico

\begin{abstract}
The general practitioner is most often the first contact physician for the patient presenting with red eye. The majority of red eye is a symptom of benign disease, such as conjunctivitis, episcleritis and subconjunctival hemorrhage, which can resolve on its own or by non-prescription medication and treatment in the primary care setting. Red eye caused by scleritis, keratitis, foreign bodies, trauma, chemical exposure, cellulitis and acute angle-closure glaucoma can be sight-threatening, and there are a myriad of differential diagnoses, including systemic diseases, that can be life-threatening and require referral to an ophthalmologist. We provide an updated general review of the benign causes of red eye and recommend guidelines to provide a comprehensive assessment, accurate diagnosis and successful management for first contact physicians and primary care providers, with the aim to reduce misdiagnoses and strengthen the referral of patients with sight- and lifethreatening disorders to ophthalmologists. Given the limited training, equipment and tools primary care providers have in ophthalmology, it is important that these clinicians can correctly assess red eye to identify benign or non-serious conditions and recognize when a case merits urgent referral, always keeping in mind that any case of red eye may require intervention by an ophthalmologist. It is important that the first contact physician or primary care provider knows the characteristics of the red eye that require an urgent assessment by an ophthalmologist. Patients whose symptoms persist, worsen or recur after initial treatment should also be urgently referred to an ophthalmologist.
\end{abstract}

Keywords: Red eye; Acute disease; Sight-threatening disease; Diagnosis; Management; Primary care; General practitioner

Abbreviations: AACG: Acute Angle-Closure Glaucoma; HSV: Herpes Simplex Virus; HZV: Herpes Zoster Virus; IOP: Intraocular Pressure; US: United States; VZV: Varicella Zoster Virus

\section{Introduction}

Red eye, an anterior segment inflammation with conjunctival or scleral redness, is the most common ocular complaint of patients in primary care, but most primary care providers have very limited training in ophthalmology [1-6]. Conjunctivitis is the principal cause of red eye treated in primary care, comprising $1 \%$ of all office visits and affecting 6 million patients in the United States (US) annually, 70\% of whom do not go to an ophthalmologist for medical attention [7-10]. Conjunctivitis may be viral, allergic or bacterial; bacterial conjunctivitis is the cause of half of cases of conjunctivitis and costs the US up to $\$ 875$ million each year $[7,11]$. The majority of red eye is a symptom of benign disease, such as conjunctivitis, as well as episcleritis and subconjunctival hemorrhage, and can be treated in the primary care setting [1-7,12,13]. Red eye caused by scleritis, keratitis, foreign bodies, trauma, chemical exposure, cellulitis and Acute Angle-closure Glaucoma (AACG) can be sight-threatening, and there are a myriad of differential diagnoses, including systemic diseases, that can be life-threatening and require referral to an ophthalmologist.

Unfortunately, $64 \%-84 \%$ of cases are misdiagnosed as conjunctivitis, leading to adverse outcomes in $12 \%$ of patients $[1,14]$. A correct diagnosis is paramount and primary care providers should be educated on the red flags for serious disease that warrant a referral to an ophthalmologist, especially considering that epidemiologic studies have demonstrated that after conjunctivitis, the most common causes of red eye are trauma and foreign bodies [15-18], which can lead to vision loss without immediate attention. Patients with red eye should be immediately referred to an ophthalmologist if they have severe eye pain, evidence of foreign body or penetrating trauma, photophobia, anisocoria, reduced visual acuity, ciliary flush, headache and nausea, corneal ulceration, purulent discharge and hyperemia, shallow anterior chamber, proptosis with pain on eye movement and increased Intraocular Pressure (IOP) $[1,4,13,19,20]$.

We provide an updated general review of the benign causes of red eye and recommend guidelines to provide a comprehensive assessment, accurate diagnosis and successful management of red eye for first contact physicians and primary care providers, with the aim to reduce misdiagnoses of red eye and strengthen the referral of patients with sight- and life-threatening disorders to ophthalmologists.

\section{Materials and Methods}

A general literature search was performed on PubMed using the search term "red eye" for articles dating from July 2013 through July 2018. Abstracts were scanned to retrieve articles that addressed red eye assessment, diagnosis and treatment and management. References of each article retrieved were also included, as appropriate.

\section{Results and Discussion}

Red eye encountered by the first contact physician and primary care providers

The characteristics and complaints of patients presenting with

*Corresponding author: Van C Lansingh, MD, PhD, Mexican Institute of Ophthalmology, Exterior Circuit Corregidora Stadium S/N, Col. Colinas del Cimatario C.P. 76099, Queretaro, Queretaro, Mexico, Tel: (+52) (442) 2290776 ; E-mail: van.lansingh@imoiap.edu.mx

Received: October 01, 2018; Accepted: December 04, 2018; Published: December 13, 2018

Citation: Lansingh VC, Eckert KA, Ramos SV, Star EML (2018) From Acute Disease to Red Flags: A Review of the Diverse Spectrum of Red Eye Encountered in the Primary Care Setting. Prim Health Care 8: 316. doi: 10.4172/21671079.1000316

Copyright: (c) 2018 Lansingh VC, et al. This is an open-access article distributed under the terms of the Creative Commons Attribution License, which permits unrestricted use, distribution, and reproduction in any medium, provided the original author and source are credited. 
common causes of red eye in the primary care setting are summarized in Table 1. For each ocular disorder, the eye's redness, pain/discomfort felt, presence of tearing/discharge, state of the pupils, state of the anterior chamber (when shining a pen light in the eye), presence of normal or reduced vision, presence of photophobia and other characteristics are described. More details are provided below for each condition.

Conjunctivitis: Conjunctivitis is an infection or inflammation of the palpebral conjunctiva and bulbar, with pronounced blood vessels, cellular infiltration and discharge [6,7,12] (Figure 1). Infectious conjunctivitis can be bacterial, viral, fungal or parasitic. Non-contagious conjunctivitis can be allergic resulting from seasonal allergies or more serious, sight-threatening vernal or atopic keratoconjunctivits, or it can be caused by environmental contaminants and irritants, reduced tear production, or malpositioned eyelids. Neonates can also experience a chemical conjunctivitis caused by a topical bactericidal placed in the eye upon birth [21-24]. In addition to red eye, patients may feel a

\begin{tabular}{|c|c|c|c|c|c|c|c|c|}
\hline $\begin{array}{l}\text { Ocular } \\
\text { Disorder }\end{array}$ & $\begin{array}{l}\text { Degree of } \\
\text { Redness }\end{array}$ & $\begin{array}{c}\text { Degree of Pain/ } \\
\text { Discomfort Reported }\end{array}$ & $\begin{array}{l}\text { Tearing/ } \\
\text { Discharge } \\
\text { Present }\end{array}$ & Pupils & $\begin{array}{l}\text { Visual } \\
\text { Acuity }\end{array}$ & Photophobia & Other Manifestations & REF \\
\hline Conjunctivitis & $\begin{array}{l}\text { Conjunctival } \\
\text { membrane } \\
\text { completely red, } \\
\text { tarsal vessels } \\
\text { obscured }\end{array}$ & $\begin{array}{l}\text { - None to minimal in } \\
\text { most cases } \\
\text { - Severe bilateral pain } \\
\text { and itching when } \\
\text { viral and allergic } \\
\text { - Foreign body } \\
\text { sensation when } \\
\text { allergic }\end{array}$ & $\begin{array}{ll}\text { - } & \text { Epiphora } \\
\text { yellow } \\
\text { mucous } \\
\text { when } \\
\text { bacterial } \\
\text { - Watery } \\
\text { mucous } \\
\text { when viral/ } \\
\text { allergic } \\
\text { Thick, ropy } \\
\text { mucous } \\
\text { when VKC }\end{array}$ & Normal & $\begin{array}{l}\text { Normal or } \\
\text { may be } \\
\text { blurred }\end{array}$ & $\begin{array}{l}\text { May occur } \\
\text { among viral } \\
\text { and VKC } \\
\text { cases }\end{array}$ & 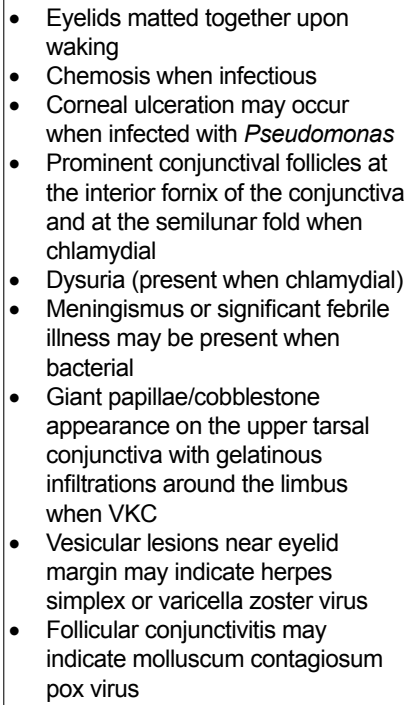 & $\begin{array}{c}{[6,12,13,19} \\
21-24]\end{array}$ \\
\hline Episcleritis & \begin{tabular}{|l|} 
Acute onset \\
and conjunctival \\
injection affecting \\
single quadrant of \\
interpalpebral zone
\end{tabular} & $\begin{array}{l}\text { Minor tenderness to } \\
\text { moderate pain can be } \\
\text { reported }\end{array}$ & $\begin{array}{c}\text { Tearing, but } \\
\text { may be minimal }\end{array}$ & Normal & Normal & $\begin{array}{l}\text { May be } \\
\text { minimal }\end{array}$ & & {$[6,13,20,27.28]$} \\
\hline Scleritis & $\begin{array}{l}\text { Deeper injection, } \\
\text { multiple quadrants } \\
\text { may be affected }\end{array}$ & Severe pain & $\begin{array}{l}\text { Occasional } \\
\text { tearing }\end{array}$ & Normal & $\begin{array}{l}\text { May be } \\
\text { reduced }\end{array}$ & May occur & $\begin{array}{l}\text { Scleral ulceration and perforation may } \\
\text { result }\end{array}$ & {$[6,13,20,27]$} \\
\hline $\begin{array}{l}\text { Sudden } \\
\text { subconjunctival } \\
\text { hemorrhage }\end{array}$ & $\begin{array}{l}\text { Acute onset } \\
\text { of sharply } \\
\text { demarcated, } \\
\text { localized redness }\end{array}$ & None & None & Normal & Normal & None & & {$[6,13,29,30]$} \\
\hline $\begin{array}{l}\text { Acute angle- } \\
\text { closure } \\
\text { glaucoma }\end{array}$ & $\begin{array}{l}\text { Diffused red eye } \\
\text { with ciliary flush }\end{array}$ & $\begin{array}{ll}\text { - } & \text { Moderate to severe } \\
\text { - Nausea }\end{array}$ & None & Mid-dilated & Reduced & 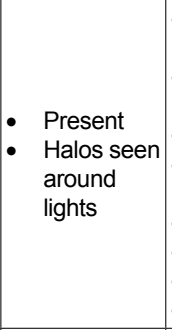 & $\begin{array}{l}\text { - Shallow anterior chamber and } \\
\text { opaque cornea } \\
\text { - } \text { "Rock-hard" eyeball shown by } \\
\text { palpation of each eye } \\
\text { - } \text { Intraocular pressure }>30 \mathrm{mmHg} \\
\text { - } \text { Headache (maybe misdiagnosed } \\
\text { - Vomiting } \\
\text { - Anxiety/distress } \\
\text { - Secondary abdominal symptoms } \\
\text { - Cardiac rhythm disorders }\end{array}$ & {$[6,12,13,20,31]$} \\
\hline $\begin{array}{l}\text { Exposures } \\
\text { (chemical and } \\
\text { poison) }\end{array}$ & Acute onset & $\begin{array}{ll}\text { - } & \text { Severe pain } \\
\text { - } & \text { Foreign body } \\
\text { - } & \text { sensation } \\
\text { - } & \text { Nausea may be felt }\end{array}$ & $\begin{array}{c}\text { Tearing may be } \\
\text { present }\end{array}$ & Normal & $\begin{array}{l}\text { May be } \\
\text { reduced }\end{array}$ & Present & $\begin{array}{l}\text { - Conjunctivitis may be present } \\
\text { - } \quad \text { Constant blinking may occur } \\
\text { - } \quad \text { Conjunctival and scleral ischemia } \\
\text { with "porcelainized" cornea when } \\
\text { exposed to severe alkali chemicals }\end{array}$ & {$[20,32-34]$} \\
\hline $\begin{array}{l}\text { Corneal } \\
\text { abrasions/ } \\
\text { foreign bodies }\end{array}$ & $\begin{array}{l}\text { Hyphema and/or } \\
\text { subconjunctival } \\
\text { hemorrhage } \\
\text { around the } \\
\text { cornea or iris with } \\
\text { penetrating trauma }\end{array}$ & Moderate to severe & Tearing & \begin{tabular}{|} 
Peaked \\
pupil with \\
penetrating \\
trauma, \\
otherwise \\
normal
\end{tabular} & $\begin{array}{l}\text { May be } \\
\text { reduced }\end{array}$ & Present & & {$[6,20,21]$} \\
\hline
\end{tabular}

REF: References; VKC: Vernal Keratoconjunctivitis.

Table 1: Clinical characteristics and complaints of common causes of red eye presenting in primary care settings. 


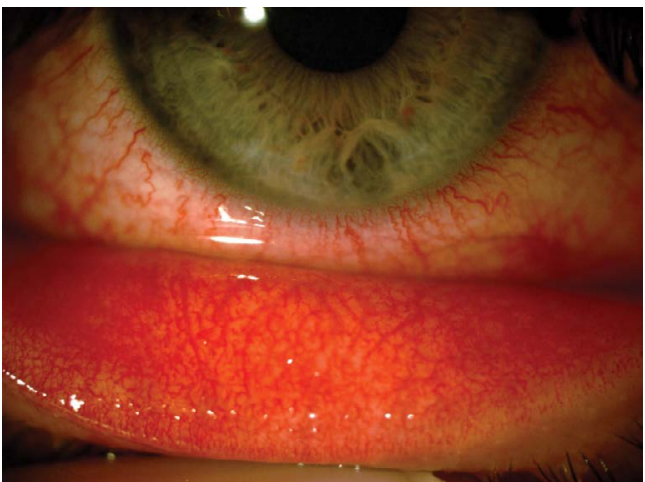

Figure 1: An example of viral conjunctivitis with inflammation of the bulbar and tarsal conjunctiva and showing pronounced blood vessels.

foreign body or pressure in the eye, and additional complaints may be reported depending on the type of conjunctivitis (Table 1)

The majority of conjunctivitis is viral or bacterial, the former occurring more frequently in summer and the latter occurring more frequently in winter and spring [6,7]. Adenovirus, enterovirus, Herpes simplex virus (HSV) and Herpes zoster virus (HZV) are common viruses that result in conjunctivitis, which usually develops first in one eye and manifests in the second eye after several days via autoinoculation $[6,7,21]$. There is usually a history of systemic upper respiratory infection and pharyngoconjunctival fever $[7,21]$. Viruses transmitted by mosquito vectors, such as chikungunya, can also cause red eye with conjunctivitis, particularly in people with systemic diseases, such as hypertension, cancer and diabetes [25].

Bacterial conjunctivitis is commonly caused by Staphylococcus aureus, Streptococcus pneumoniae, Haemophilus influenzae, Neisseria gonorrhoeae, Chlamydia trachomatis and diphtheria [6,7,21]. Patients who wear contact lenses are susceptible to Pseudomonas aeruginosa found in contact lens fluid and/or containers, a potentially serious infection with which corneal ulceration may occur [6]. The majority of patients with chlamydial conjunctivitis will also have a genital traction infection, but they are not uncommonly asymptomatic [22,26].-

Episcleritis $v \boldsymbol{s}$ scleritis: It is extremely important that general practitioners are aware of the difference between episcleritis (Figure 2) and scleritis (Figure 3), given that the former is relatively benign and the latter is much more serious with sight-threatening associations (Table 1). Episcleritis is the inflammation of the connective tissue between the sclera and conjunctive (Figure 2), which usually presents during the spring and fall in intermittent intervals of 7 to 10 days for up to 3 months $[6,13,20,27,28]$. It more commonly presents in women aged 40 to 50 years --and while it is usually idiopathic-- it can be associated with systemic autoimmune disease $[13,20,27,28]$. Bilateral recurrent episcleritis suggests systemic disease [27,28]. When HZV is the underlying disease, episcleritis might progress into scleritis [27]. Where episcleritis is a superficial scleral inflammation, scleritis runs deeper (Table 1 and Figure 3). Scleritis is more likely to be associated with autoimmune diseases and is sight-threatening, with keratitis, uveitis and glaucoma being potential risks [20]; therefore, patients should be referred to an ophthalmologist for diagnosis and care.

Subconjunctival hemorrhage: Subconjunctival hemorrhage is when blood from a ruptured conjunctival blood vessel pools under the conjunctiva (Figure 4), with no further symptoms noted (Table 1). The sclera may be completely covered by blood in severe cases

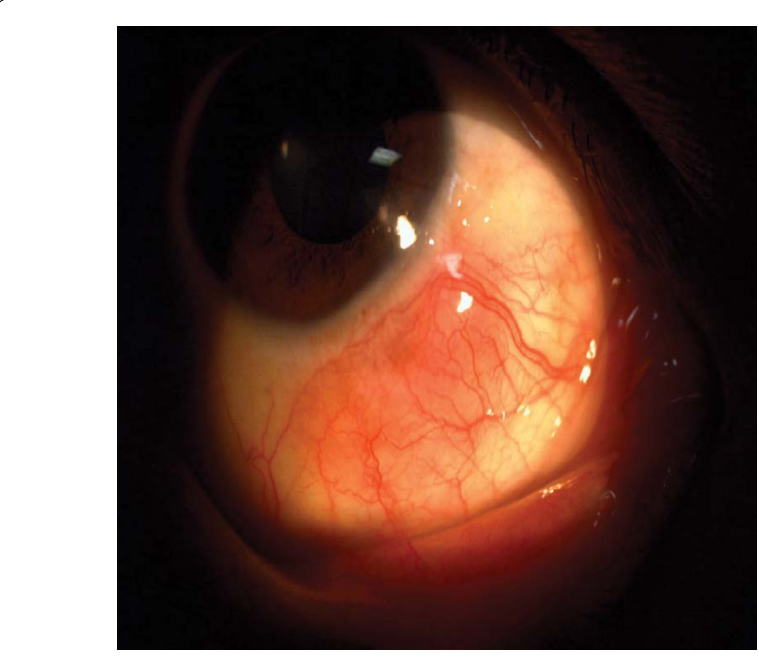

Figure 2: An example of episcleritis.
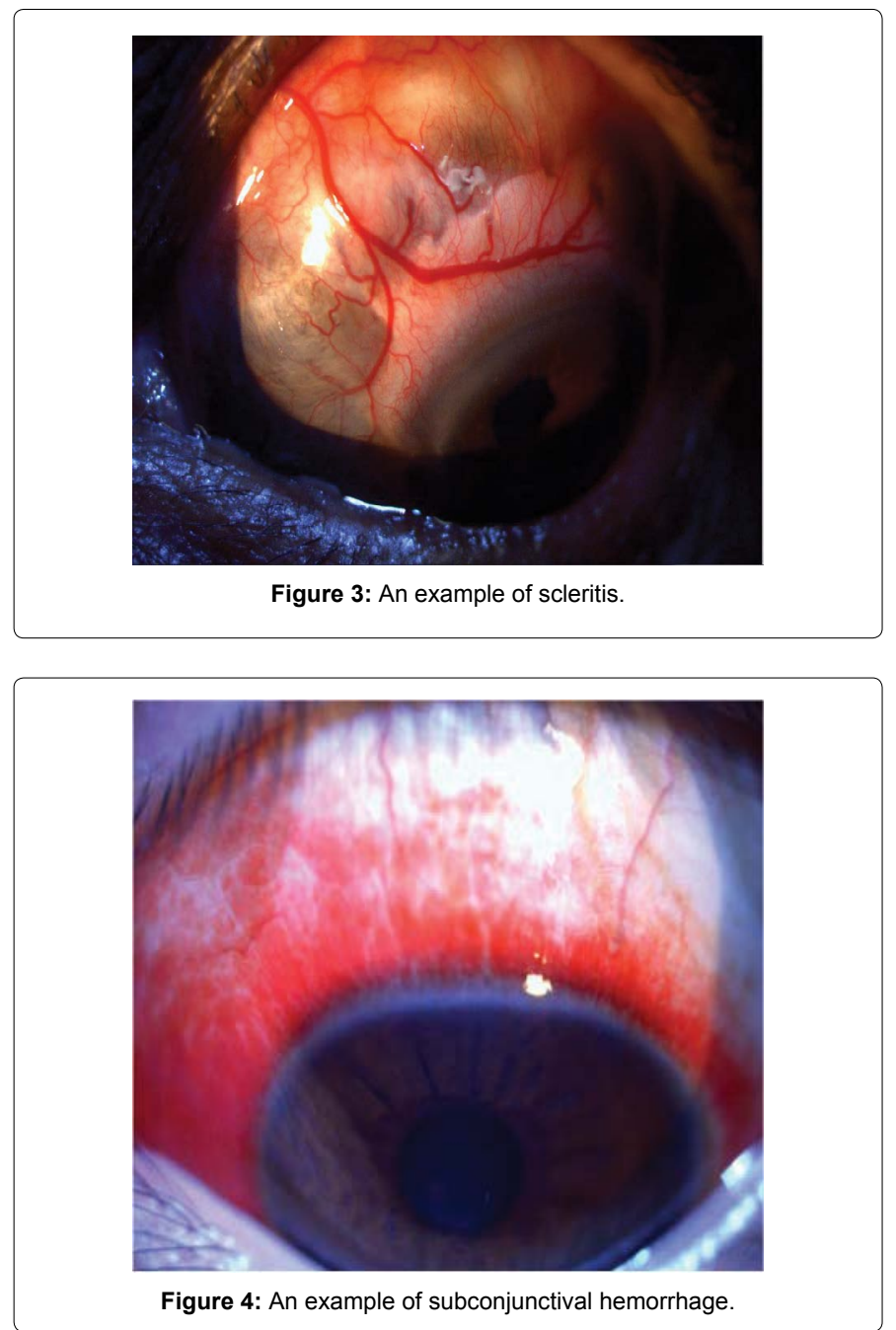

[29]. The condition is often caused by minor trauma such as Valsalva maneuvers (straining, sneezing, coughing, gardening, etc.) $[13,29,30]$. Other important risk factors include hypertension, diabetes, bleeding disorders and anticoagulants [6,29]. 
Exposure: Exposure to chemicals, including insecticides and repellents, concentrated laundry detergent packs, edible marijuana and poison from Bombina toads, has been reported by recent epidemiological studies as a cause of red eye [31-37]. These painful exposures (Table 1) are more common in young children. The $\mathrm{pH}$ concentration and chemical nature of the solution determines the severity of the exposure, with alkali being more damaging than acidic solutions [20].

Acute angle-closure glaucoma: An ocular emergency requiring immediate referral to an ophthalmologist, AACG is defined as when the anterior chamber drainage angle closes or narrows, which obstructs aqueous outflow, causing a sudden, drastic increase in IOP from a normal range of $14-21 \mathrm{mmHg}$ to a higher range of $30-70 \mathrm{mmHg}$, which can result in intraocular ischemia and optic nerve damage (and eventual) blindness $[6,12,13,20]$. Ocular pain radiating to the periocular and frontal region, the appearance of halos around light and a mid-dilated pupil, are the classic symptoms of AACG (Table 1). Risk factors for AACG include older age, female sex, sustained dilation (from certain medications), occasional excessive pupil dilation (from emotions or exposure to low light), shallow anterior chamber, Asian ethnicity and hyperopia $[6,12,20]$. Of note, some patients presenting with AACG are misdiagnosed as migraine crisis [31].

Corneal abrasions, foreign bodies, trauma: Corneal abrasions and foreign bodies in the cornea can cause pain that lasts up to 2 days and present with tearing and photophobia (Table 1). These symptoms can be caused by trauma, improper contact lens use, improper handling of animals and at-risk work, such as manufacturing and construction that require eye protection $[6,38,39]$. Any case of ocular trauma or corneal abrasion should also be evaluated for globe rupture, which can cause sight-threatening blindness if left untreated [20]. Although patients can usually report the details of ocular trauma, it is extremely important that the general practitioner is familiar with signs of penetrating trauma and globe rupture, such as severe pain, a peaked, tear-shape pupil with hyphema and/or subconjunctival hemorrhage around the cornea or iris and reduced visual acuity (Table 1), as this condition is an ocular emergency, it requires immediate referral to an ophthalmologist $[20,21]$.

Assessment and diagnosis: The conditions causing red eye that are defined in the preceding section are just a sample of some of the more common red-eye disorders seen in a primary care setting. A patient with a painful red eye may also have chalazion, dry eye and blepharitis [40]. Common sight-threatening differential diagnoses also include uveitis, keratitis, orbital cellulitis, carotid cavernous fistula and endophthalmitis [40]. The differential diagnoses of red eye are prolific and a detailed description of their assessment and management processes is beyond the scope of this review. However, it is very important that the first contact physician is able to provide an adequate initial assessment of the red eye and is aware of the red flags that warrant an urgent referral to an ophthalmologist for more comprehensive examination. Approximately 4 out of 5 of patients with AACG were misdiagnosed by their general practitioner in one study [5,41], an error that could cost patients their sight and can be avoided in primary care with improved physician education.

Primary care providers vary in their knowledge and skill set with ophthalmic diagnostic tools and assessments. A major disadvantage that general practitioners face when assessing red eye is their lack of access to or training on a slit lamp, which assesses anterior chamber inflammation and is often necessary for the differential diagnoses of red eye [5,6]. A general practitioner should know how to assess visual acuity; perform fluoresceinstaining assessment to identify corneal epithelial defect; perform a penlight examination to assess pupils and evaluate corneal clarity and conjunctiva and sclera redness; and obtain culture swabs of the eye to diagnose bacterial infection or HSV $[4,6,7,20,21,40]$.

During a visual acuity assessment of patients with red eye, the objective is to determine if there is reduced or variable near vision between affected non-affected eyes using a near card distanced approximately $36 \mathrm{~cm}$ from the patient's eye, with 1 eye covered while the other is tested [4]. Topical anesthetics should first be applied to the affected eyes in patients with painful corneal abrasions [6]. Patients should wear their prescribed eyeglasses, if they have them, or otherwise, the provider should use pinhole correction [6]. Reduced visual acuity is a red flag for an urgent referral to an ophthalmologist, as it might indicate sight-threatening infection, uveitis, trauma, AACG, among other serious diagnoses $[4,6,20,21,40]$.

Fluorescein examination is done using a Wood lamp or a cobalt blue lamp setting found on a direct ophthalmoscope $[4,7,20,21,40]$. First, 1-2 drops of topical anesthetic are applied to the affected eye [4,21]. Sterile saline is used to wet the fluorescein paper, which is touched to the interior lower eyelid and then the patient should blink. A corneal abrasion appears bright under the wood or cobalt blue lamp [4,6,20,24,40] (Figure 5). Punctate staining is indicative of ultraviolet keratitis, branching opacity with end bulbs suggests HSV and branching opacity without end bulbs suggests VZV, neutrotrophic epitheliopathy and Acanthamoeba $[4,6]$.

Multiple red eye diagnostic algorithms have been developed for the non-ophthalmologist [5], but they group together unrelated diagnoses $[42,43]$, or merely indicate an urgent referral to an ophthalmologist is needed in lieu of a diagnosis [16]. The Edinburgh Red Eye Algorithm is the only diagnostic algorithm that has been validated [5]. Its overall accuracy was $72 \%$, which increased to $100 \%$ for AACG and $82 \%$ for iritis. There were 6 misdiagnoses of keratitis that were examiner-related that could have been prevented if illuminated magnification was used to examine the cornea, once again demonstrating the limited tools and expertise of primary care providers when confronted with ocular problems.

Given the limited training, equipment and tools primary care providers have in ophthalmology [5], realistically, it is more important that these clinicians can correctly assess red eye to identify benign or non-serious conditions and recognize when a case merits urgent referral, always keeping in mind that any case of red eye may require

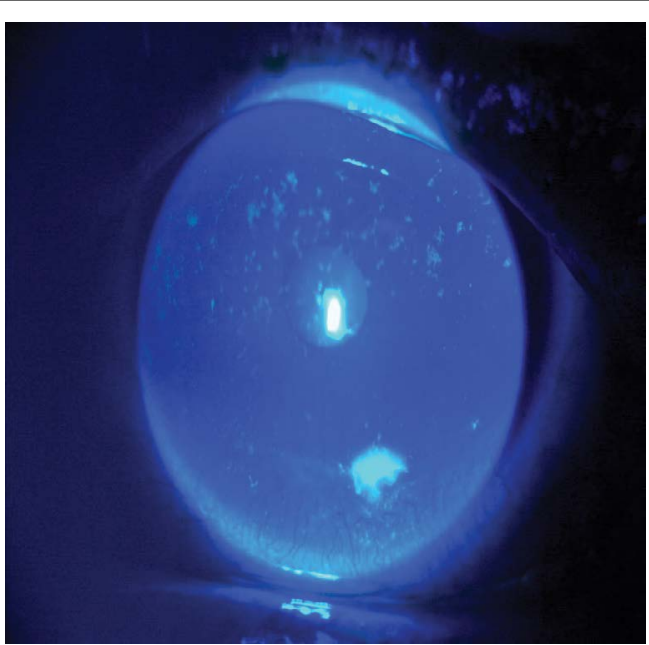

Figure 5: An example of fluorescein conjunctival staining, which shows superficial punctate keratitis with inferior corneal abrasion. 
Citation: Lansingh VC, Eckert KA, Ramos SV, Star EML (2018) From Acute Disease to Red Flags: A Review of the Diverse Spectrum of Red Eye Encountered in the Primary Care Setting. Prim Health Care 8: 316. doi: 10.4172/2167-1079.1000316

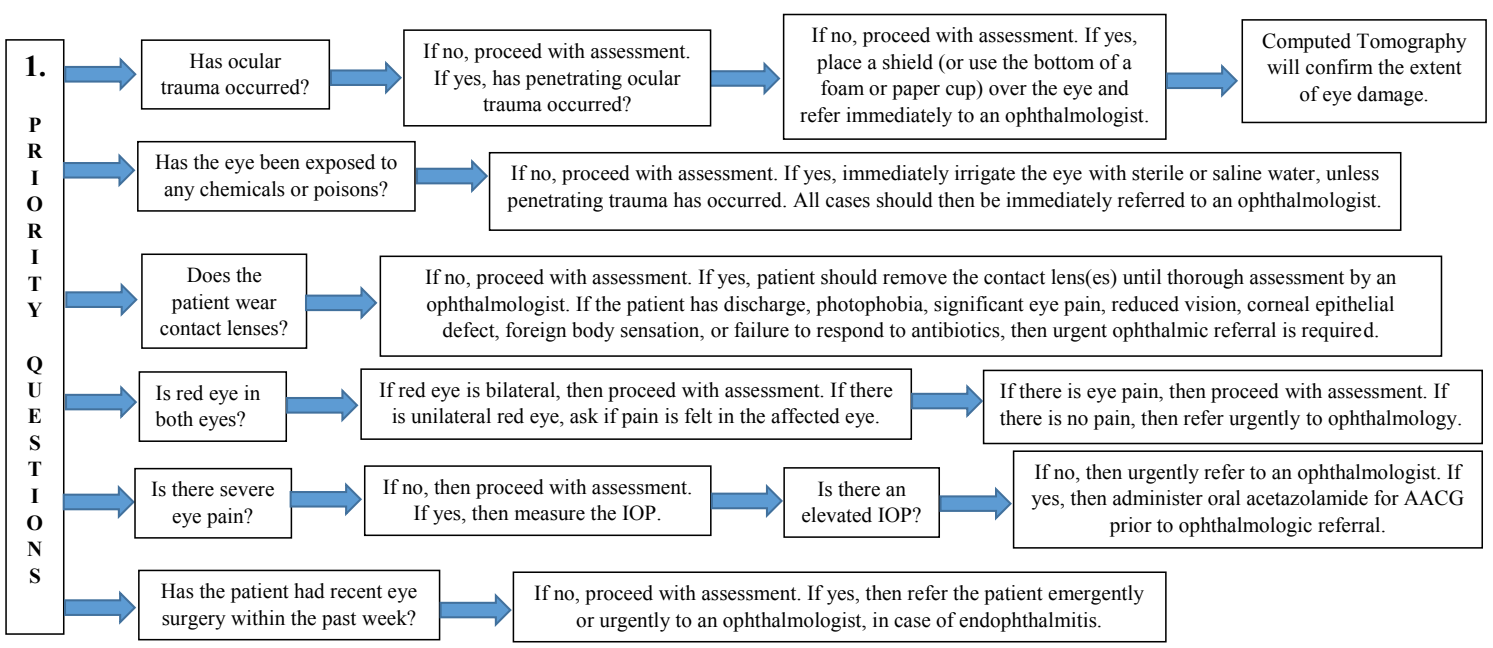

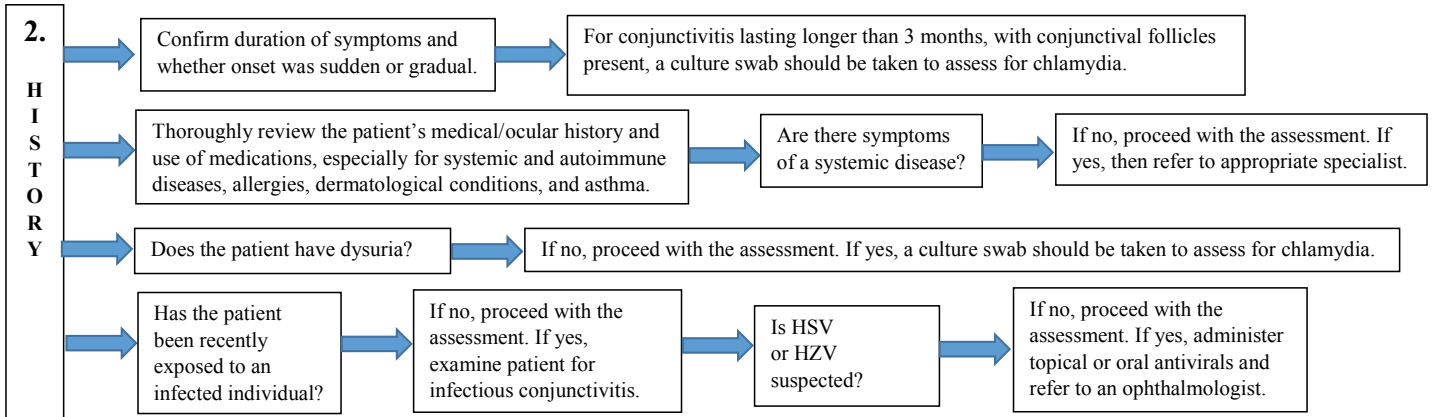

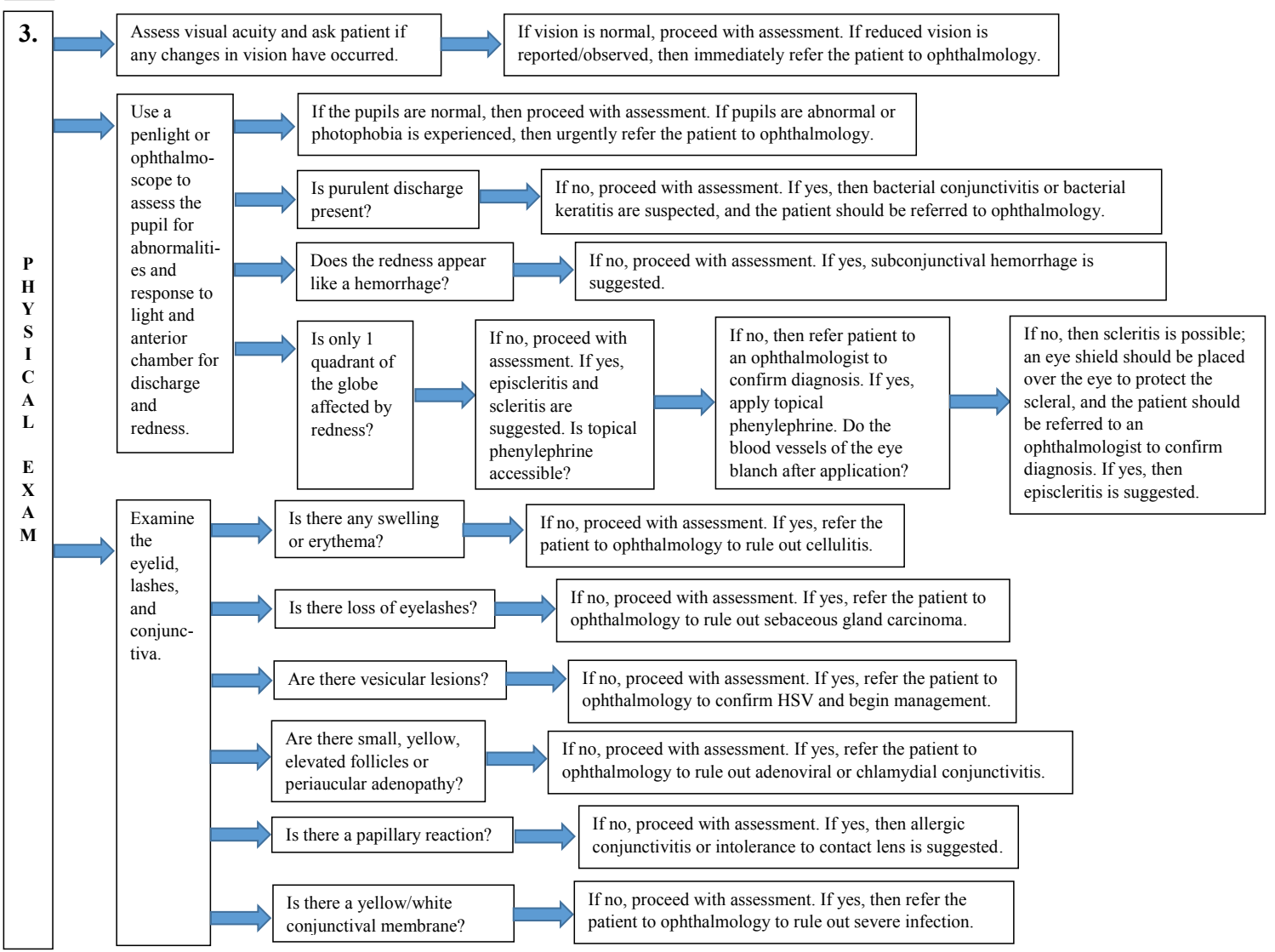

HSV: Herpes Simplex Virus; HZV: Herpes Simplex Virus

Figure 6: Red eye assessment algorithm for the primary care provider 
intervention by an ophthalmologist. Figure 6 provides the step-by-step process primary care providers and first contact physicians can take to diagnose the underlying cause of red eye and rule out the need to refer the patient to an ophthalmologist. The figure is explained below in further detail.

First and foremost, when a patient presents with red eye, the clinician should immediately assess the patient for penetrating trauma, chemical exposure and contact lens wear (Figure 6) [4,13,20,21,40,44,45]. Generally, patients can explain if ocular trauma or exposure has occurred, although this may not be the case with pediatric patients [21]. In the event of trauma, the clinician should assess the eye for signs of penetrating trauma (Table 1). Patients presenting with subconjunctival hemorrhage should be checked for globe rupture, and they should also have their blood pressure checked $[6,13,28]$. If penetrating trauma has occurred, the eye should be protected with a shield, and the patient should be immediately referred to an ophthalmologist $[4,6,13,21]$.

If chemical exposure has occurred, the eye should be immediately irrigated with sterile saline or water until the $\mathrm{pH}$ of the eye is within the normal range of 7.0 and $7.3[4,20,21,30,32]$, and the patient should then be referred to an ophthalmologist.

Contact lens use when red eye is present can be a potentially serious cause for concern. As a foreign body, when contact lenses are overused (for example, the patient does not remove them for sleeping), chronic giant papillary conjunctivitis can result, which can lead to long-term intolerance to contact lens wear; sight-threatening ulcerative keratitis can develop, which can perforate the cornea; or a sterile endophthalmitis with hypopion formation can lead to visual impairment [4,21,44-48]. The improper handling and cleaning of contact lenses (i.e., with tap water) can lead to bacterial infection, most commonly by $P$. aeruginosa and Acanthamoeba, which can be sight-threatening [45]. Patients with a history of contact lens wear, who present with red eye, purulent discharge, pain, foreign body sensation, reduced vision, corneal epithelial defect or failure to respond to antibiotics should immediately remove the contact lens and be referred for urgent assessment by an ophthalmologist for a comprehensive eye examination with a slit lamp (Figure 6) $[4,44,45]$.

It is very important for the provider to confirm if one or both eyes are affected by red eye $[4,13,20,24]$. If the red eye is unilateral and the patient reports no pain, then urgent referral to ophthalmology is indicated to rule out carotid-cavernous sinus fistula and lagophthalmos, as well as keratitis or corneal ulcer, which cause purulent discharge, photophobia and a foreign body sensation (Table 1).

Unilateral red eye with severe pain may be suggestive of a corneal abrasion, but patients with bilateral or unilateral red eye and severe eye pain should be immediately referred to an ophthalmologist. If applanation tonometry is available, then prior to their evaluation by an ophthalmologist, the IOP should be measured. An elevated IOP is indicative of AACG and requires immediate treatment, beginning with an oral dose of acetazolamide in the primary care setting, to prevent optic nerve ischemia (Figure 6) $[4,6,15]$. The general practitioner should assure patients with AACG that once their IOP is reduced, the pain will decrease [12].

Patients should also be asked if they have undergone recent eye surgery within the past week, as endophthalmitis can develop 2-7 days after surgery and requires immediate attention by an ophthalmologist (Figure 6) $[4,6,13,20]$.

After reviewing the priority concerns, the general practitioner should continue taking a thorough medical and ocular history of the patient (Figure 6) $[4,20,24]$. The provider should confirm the time course of the red eye and thoroughly review the patient's history for allergies, asthma, eczema, rosacea, seborrhea and autoimmune diseases, such as rheumatoid arthritis, Graves disease, HIV, and Sjo:rgen syndrome, which are associated with conjunctivitis. The practitioner should confirm if the patient has systemic diseases, such as diabetes and hypertension, which are known to cause subconjunctival hemorrhages and should review their medication use, as anticoagulants and antiplatelet medication can also cause subconjunctival hemorrhages [4]. Patients with conjunctivitis and signs of systemic disease should be referred to the appropriate medical specialist [24]. It is also important to confirm whether or not the patient has been exposed to an infected individual, including family members and sexual partners. If HSV or HZV is suspected, then the patient should be treated with topical or oral antivirals prior to referring to an ophthalmologist (Figure 6) [7]. If the patient has chronic conjunctivitis with conjunctival follicles that has lasted greater than 3 months, then the patient should be tested for C. trachomatis [4].

A physical exam should next be performed (Figure 6), beginning with a visual acuity assessment, which is described above in further detail $[4,7,20,24]$. It is also important to check with the patient if there are any noticeable changes in their vision. A reduction in visual acuity warrants an ophthalmologic referral. The pupil and anterior chamber of the eye should next be examined with a penlight or ophthalmoscope. If the pupils are abnormal or photophobia is observed, then the patient should be urgently referred to an ophthalmologist. Photophobia in a patient with red eye who does not experience a foreign body sensation is suggestive of uveitis and requires immediate ophthalmic attention [4]. Patterns of redness of different conditions causing red eye are reviewed in Table 1 . Of particular note is if only 1 quadrant of the globe is affected, which could suggest episcleritis or scleritis $[4,6,20,27]$. Topical phenylephrine can be applied to the affected eye and if it clears the redness, then episcleritis is suggested; if there is no change, the patient should be immediately referred to an ophthalmologist to rule out scleritis.

The practitioner should also examine the eyelids, lashes and conjunctiva for any abnormalities (Figure 6) $[7,24]$. The lower lid should be pulled and the upper lid everted to assess the palpebral conjunctiva [7].

\section{Treatment and management of conditions causing red eye}

The treatment and management of the major causes of red eye in a primary care setting are summarized in detail in Table 2. Below, some key points to treating each condition are emphasized. It is important to reiterate that any red eye, even when cause by the more benign conditions, can become a serious problem if not managed properly or if no resolution is seen after initial treatment, so the general practitioner or primary care provider should always be vigilant in case the patient requires an ophthalmologic referral.

Conjunctivitis: As the most common cause of red eye, conjunctivitis is the condition most frequently treated by the general practitioner. Unfortunately, in addition to confusing viral conjunctivitis with bacterial conjunctivitis, there is a tendency to treat conjunctivitis with antibiotics, which can induce toxicity and antimicrobial resistance and cause negative visual side effects $[6,7,24,49-53]$. Acute bacterial conjunctivitis is increasingly considered a self-limiting disease; thus, it is now recommended to delay treatment for 3 days, after which if symptoms do not improve, then antibiotic therapy can be initiated $[6,7,50,53]$. Although any topical antibiotic can be used on acute bacterial conjunctivitis, gentamycin and ofloxacin are more 
Citation: Lansingh VC, Eckert KA, Ramos SV, Star EML (2018) From Acute Disease to Red Flags: A Review of the Diverse Spectrum of Red Eye Encountered in the Primary Care Setting. Prim Health Care 8: 316. doi: 10.4172/2167-1079.1000316

\begin{tabular}{|c|c|c|c|c|}
\hline Condition & Treatment & Follow-up & $\begin{array}{l}\text { When to Refer to An } \\
\text { Ophthalmologist }\end{array}$ & REF \\
\hline \multicolumn{5}{|l|}{ Conjunctivitis } \\
\hline Allergic & 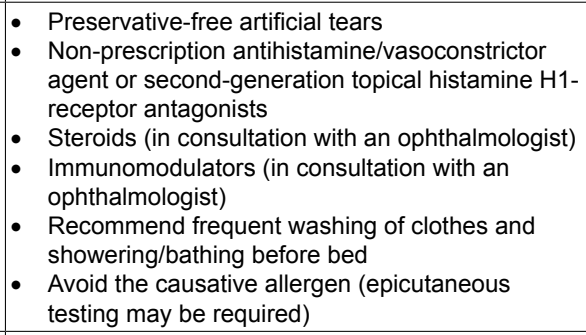 & $\begin{array}{l}\text { If persistent or recurrent, } \\
\text { administer mast- } \\
\text { cell stabilizers with } \\
\text { decongestants }\end{array}$ & $\begin{array}{l}\text { When atopic or keratoconjunctivitis } \\
\text { are suspected, which are } \\
\text { also treated with topical and } \\
\text { oral antihistamines, steroids, } \\
\text { immunomodulators, mast- } \\
\text { cell stabilizers, second- and } \\
\text { third- generation H1 blockers, } \\
\text { immunosupressants, depending } \\
\text { on severity; surgery may be } \\
\text { required when complications are } \\
\text { present }\end{array}$ & {$[6,7,13,23,24]$} \\
\hline Viral & $\begin{array}{l}\text { - Preservative-free artificial tears up to } 8 \text { times daily } \\
\text { - } \text { Cold compresses } \\
\text { isolation to prevent the spread of infection for } 2 \\
\text { weeks }\end{array}$ & $\begin{array}{l}\text { Symptoms should resolve } \\
\text { at } 1 \text { week }\end{array}$ & \begin{tabular}{|l|} 
- \\
- When no resolution after 1 week \\
(reduced vision, severe pain, \\
severe photophobia, organized \\
inflammatory membranes \\
in the cul de sac of the \\
conjunctiva) \\
- When severe cases require \\
steroids and/or tacrolimus \\
When HSV or HZV is \\
suspected
\end{tabular} & {$[6,7,21,24,49]$} \\
\hline Bacterial & $\begin{array}{l}\text { - Self-limiting } \\
\text { - Antibiotics (gentamycin or ofloxacin applied } \\
\text { topically } 3 \mathrm{x} \text { daily for } 5 \text { days) if no improvement } \\
\text { after } 3 \text { days } \\
\text { - Systemic antibiotics (single dose of } 1 \mathrm{~g} \text { of } \\
\text { azithromycin or } 100 \mathrm{mg} \text { of doxycycline twice daily } \\
\text { for } 5 \text { days) for conjunctivitis caused by chlamydia } \\
\text { or gonorrhea } \\
\text { - Dark glasses can be worn to relieve symptoms } \\
\text { - Frequent handwashing and patient education and } \\
\text { isolation to prevent the spread of infection for } 2 \\
\text { weeks } \\
\text { - If associated with chlamydia or gonorrhea, then } \\
\text { sexual partners should also be treated and all } \\
\text { affected should be referred to an appropriate } \\
\text { medical specialist }\end{array}$ & $\begin{array}{l}\text { Symptoms should improve } \\
\text { after } 5 \text { days }\end{array}$ & $\begin{array}{l}\text { If no improvement after } 5 \text { days of } \\
\text { antibiotics }\end{array}$ & {$[6,7,12,13,22,24,50,51]$} \\
\hline $\begin{array}{l}\text { Subconjunctival } \\
\text { hemorrhage }\end{array}$ & $\begin{array}{l}\text { - Usually self-limiting } \\
\text { - Lubricating drops or ointment can be used }\end{array}$ & $\begin{array}{l}\text { - Symptoms should } \\
\text { resolve after } 2 \text { weeks } \\
\text { May require additional } \\
\text { follow-up of chronic } \\
\text { health conditions }\end{array}$ & $\begin{array}{l}\text { If any complications manifest at } \\
\text { any time before resolution }\end{array}$ & {$[6,29]$} \\
\hline Episcleritis & $\begin{array}{l}\text { In consultation with an ophthalmologist following } \\
\text { initial referral, treatment can involve: } \\
\text { - Topical lubricants } \\
\text { - NSAIDs } \\
\text { - Topical steroids } \\
\text { - Cold compresses to provide relief } \\
\text { - Management of underlying systemic disease (as } \\
\text { - } \quad \text { appropriate), which may require systemic steroids } \\
\end{array}$ & $\begin{array}{l}\text { Measure the IOP at follow- } \\
\text { up should every } 2-4 \text { weeks } \\
\text { for the first } 2 \text { months of } \\
\text { treatment }\end{array}$ & $\begin{array}{l}\text { If pain worsens, then scleritis } \\
\text { is suspected, which warrants } \\
\text { immediately ophthalmologic } \\
\text { referral for confirmation of } \\
\text { diagnosis and treatment with } \\
\text { NSAIDs, pulse therapy and/or oral } \\
\text { prednisone }\end{array}$ & {$[6,20,27]$} \\
\hline $\begin{array}{l}\text { Corneal abrasion/ } \\
\text { foreign body }\end{array}$ & $\begin{array}{l}\text { - Foreign body removal by lid eversion } \\
\text { - Lubricating drops or ointment } \\
\text { - Topical antibiotics } \\
\text { o polymixin B } \\
\text { o trimethoprim } \\
\text { o polysporin } \\
\text { o quinolones when contact lens worn }\end{array}$ & $\begin{array}{l}\text { - Symptoms should } \\
\text { improve after } 24 \text { hours. } \\
\text { If contact lens are } \\
\text { worn, then follow-up } \\
\text { with ophthalmology } \\
\text { within } 48 \text { hours } \\
\text { of starting initial } \\
\text { treatment. }\end{array}$ & $\begin{array}{l}\text { If pain has not decreased within } \\
24 \text { hours of starting treatment or a } \\
\text { corneal ulcer is suspected }\end{array}$ & [6] \\
\hline
\end{tabular}

HSV: Herpes Simplex Virus; HZV: Herpes Simplex Virus; IOP: Intraocular pressure; NSAIDs: Non-steroidal anti-inflammatory drugs; REF: References.

Table 2: The treatment and management of red eye in the primary care setting.

frequently used and are applied thrice daily for 5 days [13]. If there is no improvement after 5 days, then an urgent referral to an ophthalmologist is required (Table 2). If the patient has conjunctivitis due to $C$. trachomatis or N. gonorrhoeae, then systemic antibiotic treatment is warranted from the beginning, with treatment of sexual partners to contain the disease and follow-up with an appropriate medical specialist also needed (Table 2) [24].
Viral conjunctivitis is extremely contagious; thus the isolation of patients and their providers for 2 weeks is recommended, but it should resolve after 1 week during which artificial tears and cold compresses can be used to alleviate the symptoms (Table 1). Antibiotics do not benefit viral conjunctivitis.

Allergic conjunctivitis should also resolve after use of artificial 
tears and nonprescription antihistamines and by avoiding the causative allergen (Table 1). If persistent or serious, then, as with other forms of conjunctivitis, an ophthalmologic referral is needed.

Subconjunctival hemorrhage: Subconjunctival hemorrhage is generally self-limiting, but if it has not resolved on its own after 2 weeks, then an ophthalmologic referral is required. Additional followup with the general practitioner may be necessary if it is associated with a chronic health condition (Table 1).

Episcleritis: Given the confusion between episcleritis and scleritis, it is always advised to treat the patient with episcleritis in consultation with an ophthalmologist (Table 1). This condition can be self-limiting, but it can also mask as sight-threatening scleritis, which can reveal itself over time, with worsening pain being the most notable symptom (Table 2 ). It is very important for the general practitioner to closely follow-up on the patient every 2 to 4 weeks during the first 2 months of treatment.

Corneal abrasion/foreign body: General practitioners should first perform lid eversion to remove the foreign body in the eye of a patient presenting with a corneal abrasion; lubricating eye drops or ointment and topical antibiotics can then be administered. If the symptoms do not improve within 24 hours, then the patient should be referred to an ophthalmologist to rule out a corneal ulcer (Table 1) [6]. Patients with contact lenses should be prescribed quinolones and should follow-up with an ophthalmologist within 48 hours of starting their treatment, regardless of resolution.

\section{Conclusion}

The general practitioner is most often the first contact physician for the patient presenting with red eye. The majority of red eye is caused by acute and benign conditions that can resolve on their own or by nonprescription medication and treatment. However, all cases of red eye can potentially warrant referral to an ophthalmologist. The spectrum of conditions causing red eye is vast and differential diagnoses are unfortunately common at the primary care level. Figure 6 guides the first contact physician and primary care provider through the diagnosis process at the primary care level. What is most important is to look out for the red flags of red eye which can be associated with serious, sight-threatening conditions. Patients with red eye who present with reduced visual acuity, photophobia, moderate to severe pain, headache and nausea, elevated IOP, corneal epithelial defects with associated infiltrate and/or anterior chamber inflammation, evidence of foreign body or penetrating trauma, anisocoria, ciliary flush, shallow anterior chamber or proptosis with painful extraocular muscle should be referred emergently or urgently to an ophthalmologist. Patients who initially do not present with these complications, but whose symptoms persist, worsen or recur after initial treatment should also be urgently referred to an ophthalmologist.

\section{References}

1. Kilduff C, Lois C (2016) Red eyes and red-flags: Improving ophthalmic assessment and referral in primary care. BMJ Qual Improv Rep 5: 1-8.

2. Cronau H, Kankanala RR, Mauger $T$ (2010) Diagnosis and management of red eye in primary care. Am Fam Physician 81: 137-144.

3. Wirbelauer C (2006) Management of the red eye for the primary care physician. Am J Med 119: 302-306.

4. Dunlop AL, Wells JR (2015) Approach to red eye for primary care practitioners. Prim Care 42: 267-284

5. Timlin H, Butler L, Wright $M$ (2015) The accuracy of the Edinburgh red eye diagnostic algorithm. Eye (Lond) 29: 619-624.

6. Gilani CJ, Yang A, Yonkers M, Boysen-Osborn M (2017) Differentiating urgent and emergent causes of acute red eye for the emergency physician. West $J$ Emerg Med 18: 509-517.

7. Alfonso SA, Fawley JD, Alexa Lu X (2015) Conjunctivitis. Prim Care 42: 325345.

8. Kaufman HE (2011) Adenovirus advances: New diagnostic and therapeutic options. Curr Opin Ophthalmol 22: 290-293.

9. Shields T, Sloane PD (1991) A comparison of eye problems in primary care and ophthalmology practices. Fam Med 23: 544-546.

10. Udeh BL, Schneider JE, Ohsfeldt RL (2008) Cost effectiveness of a point-ofcare test for adenoviral conjunctivitis. Am J Med Sci 336: 254-264.

11. Smith AF, Waycaster C (2009) Estimate of the direct and indirect annual cost of bacterial conjunctivitis in the United States. BMC Ophthalmol 9: 13.

12. Watkinson S (2013) Assessment and management of patients with acute red eye. Nurs Older People 25: 27-34.

13. Frings A, Geerling G, Schargus M (2017) Red eye: A guide for non-specialists. Dtsch Arztebl Int 114: 302-312.

14. Jackson CL (2009) Misdiagnosis of acute eye diseases by primary health care providers: Incidence and implications. Med J Aust 190: 343-344.

15. Farokhfar A, Ahmadzadeh Amiri A, Heidari Gorji Mohammad A, Sheikhrezaee M (2016) Common causes of red eye presenting in northern Iran. Rom J Ophthalmol 60: 71-78.

16. Cronau H, Kankanala RR, Mauger $\mathrm{T}$ (2010) Diagnosis and management of red eye in primary care. Am Fam Physician 81: 137-144.

17. Lawan A (2009) Causes of red eye in Aminu Kano teaching hospital, KanoNigeria. Niger J Med 18: 184-185

18. Petricek I, Prost M, Popova A (2006) The differential diagnosis of red eye A survey of medical practitioners from Eastern Europe and Middle East. Ophthalmologica 220: 229-237.

19. Narayana S, McGee S (2015) Bedside diagnosis of the 'Red Eye': A systematic review. Am J Med 128: 1220-1224.

20. Ossorio A (2015) Red eye emergencies in primary care. Nurse Pract 40: 46-53

21. Wong MM, Anninger W (2014) The pediatric red eye. Pediatr Clin North Am 61: 591-606.

22. Rothschild PR, Brezin AP, Dupin N (2014) A 22-year-old man with chronic red eye and dysuria. BMJ Case Rep 2014.

23. Vichyanond P, Pacharn P, Pleyer U, Leonardi A (2014) Vernal keratoconjunctivitis: A severe allergic eye disease with remodeling changes. Pediatr Allergy Immunol 25: 314-322.

24. American Academy of Ophthalmology (AAO) (2017) Cornea/external disease summary benchmarks for preferred practice patterns guidelines.

25. Ulloa-Padilla JP, Dávila PJ, Izquierdo NJ, García-Rodríguez O, Jiménez IZ (2018) Ocular symptoms and signs of chikungunya fever in Puerto Rico. P R Health Sci J 37: 83-87.

26. Soomro TN, Buchan J (2016) Comment on 'The accuracy of the Edinburgh red eye diagnostic algorithm'. Eye (Lond) 30: 164-165.

27. Salama A, Elsheikh A, Alweis R (2018) Is this a worrisome red eye? Episcleritis in the primary care setting. J Community Hosp Intern Med Perspect 8: 46-48.

28. Jabs DA, Mudun A, Dunn JP, Marsh MJ (2000) Episcleritis and scleritis: Clinical features and treatment results. Am J Ophthalmol 130: 469-476.

29. Meltzer DI (2013) Painless red eye. Am Fam Physician 88: 533-534.

30. Doğan P, İnci S, Şentürk B, Uçar FM, Güray U (2016) Red eye and red face following defibrilation. J Clin Diagn Res 10: OL02.

31. MacGregor EA (2017) Migraine. Ann Intern Med 166: ITC49-49ITC64

32. Charlton NP, Murphy LT, Parker Cote JL, Vakkalanka JP (2016) The toxicity of picaridin containing insect repellent reported to the National poison data system. Clin Toxicol (Phila) 54: 655-658.

33. Forrester MB (2018) Pediatric exposures to bombina toads reported to poison centers. Pediatr Emerg Care 34: 25-26.

34. Cao D, Srisuma S, Bronstein AC (2016) Characterization of edible marijuana 
Citation: Lansingh VC, Eckert KA, Ramos SV, Star EML (2018) From Acute Disease to Red Flags: A Review of the Diverse Spectrum of Red Eye Encountered in the Primary Care Setting. Prim Health Care 8: 316. doi: 10.4172/2167-1079.1000316

product exposures reported to United States poison centers. Clin Toxicol (Phila) 54: 840-846.

35. Forrester MB (2014) Referral of pediatric laundry detergent pack exposure reported to poison centers. J Emerg Med 47: 532-538.

36. Forrester MB (2014) Neonicotinoid insecticide exposures reported to six poison centers in Texas. Hum Exp Toxicol 33: 568-573.

37. Hu Y, Xu Y (2017) The optical imaging of tarantula hair corneal injury: One case report and review of the literature. Photodiagnosis Photodyn Ther 19: 352-354.

38. Savage NDSJ, Green JCP MRCP, Carley F FRCOphth (2018) Images in ophthalmia nodosa: An unusual presentation of red eye. BMJ Case Rep 2018.

39. Diaz JH (2015) Ocular filariasis in US residents, Returning Travelers, and Expatriates. J La State Med Soc 167: 172-176.

40. Navaratna AF, Walsh A, Magin P (2016) More than meets the (painful red) eye. Aust Fam Physician 45: 383-384.

41. Siriwardena D, Arora AK, Fraser SG, McClelland HK, Claoué C (1996) Misdiagnosis of acute angle closure glaucoma. Age Ageing 25: 421-423.

42. Morrow GL, Abbott RL (1998) Conjunctivitis. Am Fam Physician 57: 735-746.

43. Granet D (2008) Allergic rhinoconjunctivitis and differential diagnosis of the red eye. Allergy Asthma Proc 29: 565-574.

44. Bruce AS, Nguyen LM (2013) Acute red eye (non-ulcerative keratitis) associated with mini-scleral contact lens wear for keratoconus. Clin Exp Optom. 96: 245-248.
45. Aboshiha J (2013) A case of recalcitrant bacterial conjunctivitis. Practitioner 257: $25-28$.

46. Bruce AS, Brennan NA (1990) Corneal pathophysiology with contact lens wear Surv Ophthalmol 35: 25-58.

47. Snyder DA, Litinsky SM, Gelender H (1982) Hypopyon iridocyclitis associated with extended-wear soft contact lenses. Am J Ophthalmol 93: 519-520.

48. Murphy $G$ (1981) A case of sterile endophthalmitis associated with the extended wear of an aphakic soft contact lens. Contact Intraocul Lens Med J 7: 5-7.

49. González-López JJ, Morcillo-Laiz R, Muñoz-Negrete FJ (2013) Adenovira keratoconjunctivitis: An update. Arch Soc Esp Oftalmol 88: 108-115.

50. Everitt HA, Little PS, Smith PW (2006) A randomised controlled trial of management strategies for acute infective conjunctivitis in general practice. BMJ 333: 321

51. Geisler WM (2011) Diagnosis and management of uncomplicated Chlamydia trachomatis infections in adolescents and adults: Summary of evidence reviewed for the 2010 Centers for Disease Control and Prevention Sexually Transmitted Diseases Treatment Guidelines. Clin Infect Dis 53: S92-S98.

52. Visscher KL, Hutnik CM, Thomas M (2009) Evidence-based treatment of acute infective conjunctivitis: Breaking the cycle of antibiotic prescribing. Can Fam Physician 55: 1071-1075.

53. Sheikh A, Hurwitz B, van Schayck CP, McLean S, Nurmatov U (2012) Antibiotics versus placebo for acute bacterial conjunctivitis. Cochrane Database Syst Rev 9: CD001211. 